\title{
Lucien Bernot - 1919-1993
}

\section{Marie-Claude Mahias et François Sigaut}

\section{OpenEdition}

Journals

Édition électronique

URL : https://journals.openedition.org/tc/657

DOI : $10.4000 /$ tc. 657

ISSN : 1952-420X

\section{Éditeur}

Éditions de l'EHESS

\section{Édition imprimée}

Date de publication : 1 novembre 1993

ISSN : 0248-6016

\section{Référence électronique}

Marie-Claude Mahias et François Sigaut, « Lucien Bernot - 1919-1993 », Techniques \& Culture [En ligne], 20 | 1993, mis en ligne le 05 janvier 2006, consulté le 29 septembre 2022. URL : http:// journals.openedition.org/tc/657 ; DOI : https://doi.org/10.4000/tc.657

Ce document a été généré automatiquement le 29 septembre 2022.

Tous droits réservés 


\section{Lucien Bernot - 1919-1993}

Marie-Claude Mahias et François Sigaut 